\title{
Lack of association between insulin-like growth factor-I (IGF-I) gene polymorphism (rs35767) and power performance in professional, amateur athletes and non-athlete individuals in Iranian population
}

\author{
Mohammad Reza Batavani ${ }^{*}$, Sayyed Mohammad Marandi², Kamran Ghaedi ${ }^{3}$, Fahime \\ Esfarjani $^{2}$
}

1. Department of Physiology, Faculty of Center of Physical Education, Isfahan University of Technology, Isfahan 84156-83111, Iran

2. Department of Physiology, Faculty of Physical Education and Sport Sciences, University of Isfahan, Isfahan, Iran

3. Department of Biology, Faculty of Sciences, University of Isfahan, Isfahan, Iran

*Corresponding author:Tel: +98 9132398493 Fax: +98 3133912940-1

Address: Department of Physiology, Faculty of Center of Physical Education, Isfahan University of Technology, Isfahan 84156-83111, Iran

E-mail: batavani@cc.iut.ac.ir

Received; 2018/08/23 revised; 2018/09/11 accepted; 2018/10/20

\section{Abstract}

Introduction: Genetic variation between individuals may include single nucleotide polymorphisms. These individual differences could change human phenotypes (such as skeletal structure, heart and lung size). Insulin-like growth factor-I (IGF-I) is a critical factor in growth and exercise-associated muscle development. In this study we analyzed the frequency of IGF-I rs35767 polymorphism in karate-Kas athletes to find whether there is a difference among professional, amateur athletes and non- Karate-Kas.

Materials and methods: Two hundred and fifty-four athletes (95 professional Karate-Kas, and 159 amateur Karate-Kas) and 159 non-athletic healthy individuals participated in the current study. Following provision of informed consent, $2 \mathrm{~mL}$ of blood samples were taken. After DNA isolation, the genotyping frequencies of the IGF-I gene C/T polymorphism was assessed by restriction fragment length polymorphism (RFLP) analysis. Statistical analyses carried out using SPSS software (version 20) and data with $\mathrm{P}<0.05$ were considered to be significant.

Results: Frequency of $\mathrm{T} / \mathrm{T}$ and $\mathrm{C} / \mathrm{T}$ genotypes in comparison to $\mathrm{C} / \mathrm{C}$ genotype was increased in professional Karate-Kas and amateur Karate-Kas versus to control volunteer (odd ratio > 1) however, was not significant. Odd ratios of $\mathrm{T} / \mathrm{T}$ and $\mathrm{T} / \mathrm{C}$ genotypes compared to $\mathrm{C} / \mathrm{C}$ in professional group versus controls were 1.125 (95\%CI: 0.556 - 2.275) and 1.034 (0.538 1.984), respectively. Also, odd ratio of $\mathrm{T} / \mathrm{T}$ and $\mathrm{T} / \mathrm{C}$ in amateur group versus controls were 1.002 (0.535 - 1.876) and $1.256(0.715$ - 2.205), respectively.

Conclusion: The IGF-I gene $\mathrm{C} / \mathrm{T}$ polymorphism is not significantly associated with the physical performance's levels of karate-kas athletes in Iranian population.

Keywords: IGF-I, Polymorphism, Professional Karate-Kas, Amateur Karate-Kas

\section{Introduction}

Physical performance is a multifaceted phenomenon; furthermore it is dependent to both intrinsic factors (e.g., genetics and psychological profile) and extrinsic factors (e.g., training and overall health conditions). One of the most complex

Copyright (C) 2018 Journal of Basic Research in Medical Science. This is an open access article distributed under the terms of the Creative Commons Attribution 4.0 International License (https://creativecommons.org/licenses/by-nc/4.0/) which permits copy and redistribute the material, in any medium or format, provided the original work is properly cited. 
human traits is athletic performance, since depends on several body systems such as: respiratory, nervous and musculoskeletal. Individual differences of body system, are origin of variety in strength, power, body morphology and endurance, which are key factors underlying physical performance (1).

Around $40 \%$ of body mass in human consists of skeletal muscle. Since this type of muscles have numerous critical functions such as locomotion, glucose and fat metabolism and thermogenesis, the mechanisms regulating muscle growth and development are widely studied(2).Muscle is an extremely plastic tissue, which, exercise, nutrition and hormonal factors are key regulators of muscle mass(3). According dramatic effects of Anabolic steroids on muscle bulk, these hormones have long been used by body builders. Anabolic activity of insulin-like growth factor-I (IGF-I) have been demonstrated and recent studies demonstrated that exercise-associated muscle growth and development depends on IGF-I expression level(2). IGF-1 participates in diverse biological process such as: skeletal growth, cell cycle progression, differentiation, and mediator for various hormones. So numerous SNPs of IGF-1 have been studied to be involved in cancer, myopia, muscle function, BMD regulation and affects age at menarche(4, 5). C-1245T (rs35767) is one of these genetic variation that is located in IGF-I gene's promoter. Previous studies have demonstrated that rs35767 is associated with the endurance performance and power in athletics (6).

Karate, the Japanese word for "empty hands", developed in Japan in the early 17 th century. Four karate styles are categorized by the World Karate Federation: Goju, Shito, Shotokan and Wado. Chaabène et al. reviewed physical and physiological features of karate athletes in several aspect such as Body Composition, Bone Mineral Density, Aerobic and Anaerobic Profile, Muscle Power and Flexibility (7). It is reported that achieving top karate performances depends on muscle explosive power plays a major role in $(8,9)$. In this study, we aimed to investigate the frequency of rs35767, in three groups of professional karate-kas, amateur athletes and nonathletes.

\section{Materials and methods}

Subjects: 254 Karate-kas (95 professional Karate-kas, and 159 amateur Karate-kas) and 159 non-athletes participated in this case-control study. All subjects in professional group were member of Iran national teams who has earned a medal or worthy score in world, Asian, international or national championships. All members in amateur group succeeded to take the black belt in karate (at least four years' experience in karate), but they didn't succeeded to get any score or medal in aforementioned championships. The main condition for including subjects in the control group was the absence of previous experience in any sport on a regular basis. After signing an informed consent form for agreement to participation in this study by the persons, $2 \mathrm{~mL}$ of blood sample was taken from each individual and collected in EDTA contain tubes.

DNA isolation: In this process, $2 \mathrm{~mL}$ blood samples were taken from each individual, after completing a consent form. Genomic DNA was extracted from peripheral blood samples using standard salting out procedure and for evaluate quantity and quality of extracted DNA, absorbance at 260/280 nm, measured by a NanoDrop spectrometer (Nanodrop 1000; Thermo Scientific, Wilmington, NC, USA), and by electrophoresis on $1 \%$ agarose gel. Extracted DNAs were stored at $-20{ }^{\circ} \mathrm{C}$ till 2further usage for genotyping analysis. Genotyping: Allele specific PCR (ASP) was utilized to genotyping rs35767. To perform ASP, three primers designed (Table 1) and purchased from MacrogenInc (Seoul, Korea), one common primer and two allele specific primers 
which used in separate set of PCR. Primers were purchased from MacrogenInc (Seoul, Korea). PCR reactions were performed by PCR kit (Fermentas, Thermo Scientific, Germany) in a total volume of $25 \mu \mathrm{L}$ containing 50-100 ng of genomic DNA, $2.5 \mu \mathrm{L}$ of $10 \mathrm{X}$ PCR buffer containing 50 $\mathrm{mM} \mathrm{MgCl} 2$ (Sinaclon), $1 \mu \mathrm{L}$ of 5 pmol of each primer, $0.5 \mu \mathrm{L}$ of dNTPs mix (10 $\mathrm{mM}), 1 \mathrm{U} / \mu \mathrm{L}$ of taq DNA polymerase and deionized water. PCR products were analyzed by electrophoretic separation on $1 \%$ agarose gel followed by staining with ethidium bromide and visualization in transmitted ultraviolet light.

\section{Statistical analysis}

Statistical Package for the Social Sciences (SPSS) (Ver. 20) software used for statistical analysis. Calculation of Odds ratio (OR) with $95 \%$, confidence intervals (95\% CI) was used to assess correlations between SNPs and Professional, Amateur Athletes possibility.

\section{Results}

The electrophoresis of the PCR products were led to diagnosis of the types of the allele $(\mathrm{C} / \mathrm{C}$ or $\mathrm{T} / \mathrm{T}$ in case of 1 response [just response of $\mathrm{C}$ or $\mathrm{T}$ allele, respectively], and $\mathrm{C} / \mathrm{T}$ in case of 2 response [both responses of $\mathrm{C}$ and $\mathrm{T}$ allele]) and genotype of all subjects (Figure 1). The distribution analyses of genotype frequency by the IGF1 gene $(\mathrm{C} / \mathrm{T}$ polymorphism) in Professional, Amateur karate-kas and Non-athlete groups are shown in Figure 2.

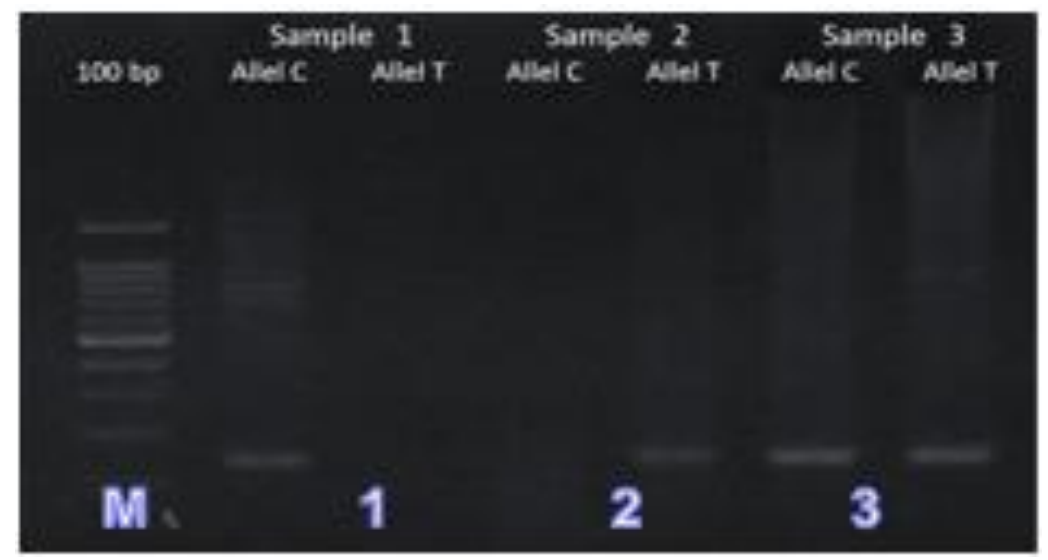

Figure1. Representative of an agaros gel electrophoresis of PCR partial products of IGF1 gene. 1; CC genotype (1 response to $\mathrm{C}$ allele), 2; TT genotype (1 response to $\mathrm{T}$ allele) and lanes 3; CT genotype (1 response to $\mathrm{C}$ allele and 1 response to $\mathrm{T}$ allele). $\mathrm{M}$ is DNA $100 \mathrm{bp}$ ladder (Fermentas).

Statistical analysis performed by multinomial logistic regression for differentiating three groups to estimate OR of each genotype (Table 2). As shown in Table 2, there is no statistical significant association between IGF-I Gene Polymorphism (rs35767) and Professional, Amateur karate-kas and Non-athlete groups. Frequency of $\mathrm{T} / \mathrm{T}$ and $\mathrm{C} / \mathrm{T}$ genotype in comparison to $\mathrm{C} / \mathrm{C}$ genotype increased in two groups of Karate-kas versus to Non-athlete group (OR > 1).

\section{Discussion}

As mentioned previously, rs 35767 is located in IGF-I gene's promoter. Association between IGF1 and rs35767 polymorphism demonstrated by Palles and colleagues already (10).Since IGF1 have key role in variety of physiological process, lot of studies focused on rs35767 in diversity of condition such as agerelated decrease in muscle mass and strength, physical ability, baseline free fat 
mass, body composition and muscle function(11-14).

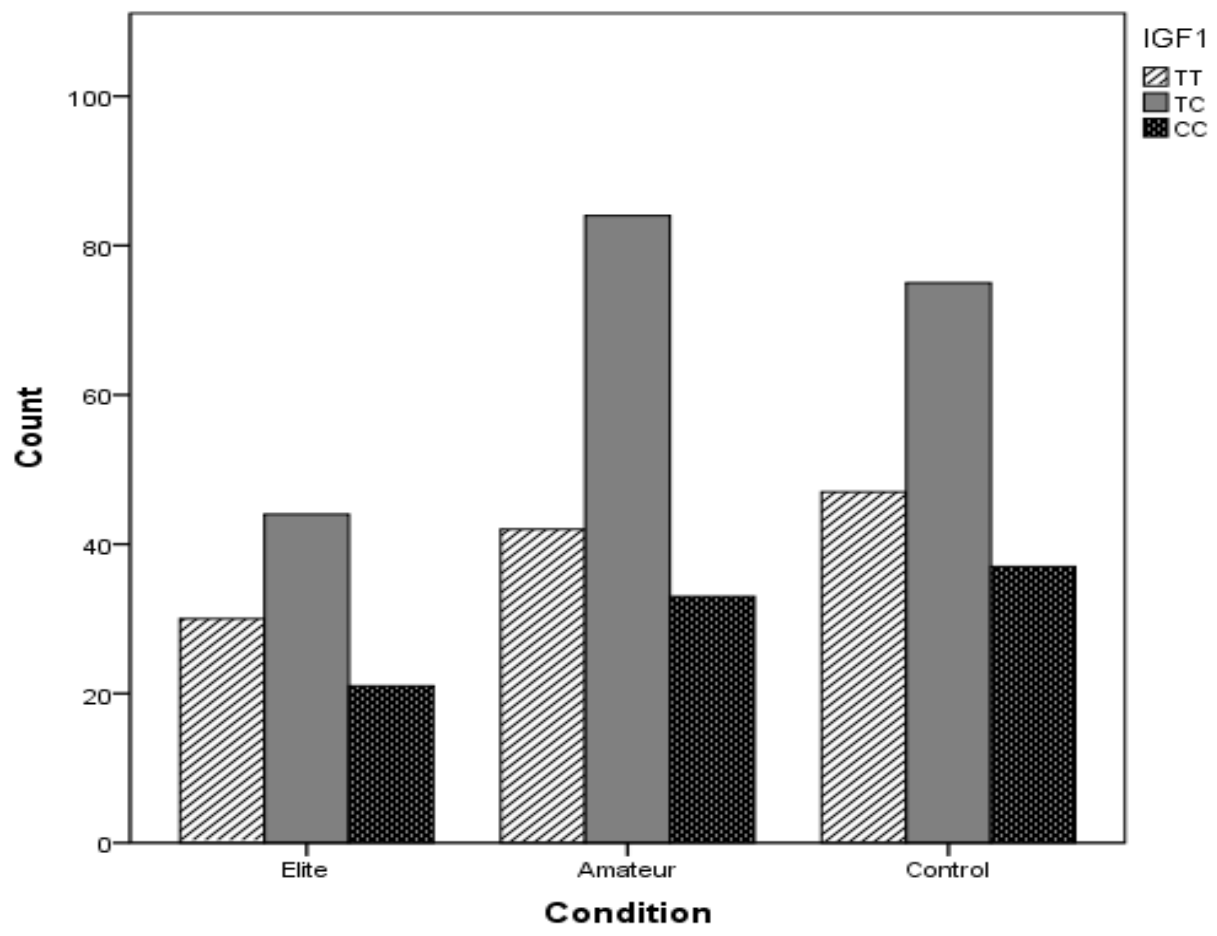

Figure 2. Frequency of TT, TC and CC genotype in three groups of study. Professional Karate-Kas (Elite), amateur Karate-Kas (Amateur) and nonathletic healthy individuals (Control).

Table 2. Multinomial logistic regressions for rs35767 in professional, amateur athletes and non-athlete groups.

\begin{tabular}{|c|c|c|c|c|}
\hline & \multicolumn{2}{|c|}{ Professional Karate-Kas } & \multicolumn{2}{|l|}{ Amateurs } \\
\hline IGF-I Gene Polymorphism (rs35767) & Odds Ratio(95\% CI) & $\mathrm{P}$ value & Odds Ratio(95\%CI) & P value \\
\hline $\mathrm{T} / \mathrm{T}$ & $1.12(0.56-2.27)$ & 0.74 & $1.00(0.54-1.88)$ & 0.99 \\
\hline $\mathrm{T} / \mathrm{C}$ & $1.03(0.54-1.98)$ & 0.92 & $1.27(0.71-2.20)$ & 0.43 \\
\hline $\mathrm{C} / \mathrm{C}$ & 1.000 & & 1.000 & \\
\hline
\end{tabular}

Although association of IGF1 polymorphism and professional athletes reported previously in Poland and Israel's population $(6,15)$, but in Iranian population no significant association observed. Recently Miyamoto-Mikami and colleagues(16),21 genetic markers in Japanese sprint/power track and field athletes and assessed total genetic score (TGS), proposed by Williams and Folland (17) as a genetic algorithm to predict the genetic potential for endurance performance. But finally reported that the TGSs based on the selected genetic markers, were not able to predict the difference in Japanese population. Therefore based on this study and our result, there is differences in genotypephenotype associations between Asian and Caucasian populations.

\section{Conclusion}

Taken together with our present casecontrol study indicate that rs35767, the IGF-I gene $\mathrm{C} / \mathrm{T}$ polymorphism, is not significantly associated with the physical performance's levels of karate-kas athletes in Iranian population. However, genetic analysis on a larger population is required.

\section{Acknowledgments}

This study was supported by the office of vice chancellor for research and 
technology of the University of Isfahan to support the $\mathrm{PhD}$ graduation of Mohammad Reza Batavani.

\section{References}

1. Guth LM, Roth SM. Genetic influence on athletic performance. Curr Opin Pediatr. 2013;25(6):653-8. doi: 10.1097/MOP.0b013e3283659087.

2. Velloso C. Regulation of muscle mass by growth hormone and IGF- I. British journal of pharmacology. 2008;154(3): 557-68. doi: 10.1038/bjp.2008.171.

3. Rennie MJ, Wackerhage $\mathrm{H}$, Spangenburg EE, Booth FW. Control of the size of the human muscle mass. Annu Rev Physiol. 2004; 66:799-828. doi.org/10.1146/annurev.physiol.66.05 2102.134444.

4. Zhao J, Xiong DH, Guo Y, Yang TL, Recker RR, Deng HW. Polymorphism in the insulin-like growth factor 1 gene is associated with age at menarche in caucasian females. Hum Reprod. 2007;22(6):1789-94. doi.org/10.1093/humrep/dem052.

5. Kostek MC, Devaney JM, GordishDressman H, Harris TB, Thompson PD, Clarkson PM, et al.. A polymorphism near IGF1 is associated with body composition and muscle function in women from the Health, Aging, and Body Composition Study. Eur J Appl Physiol. 2010;110(2):31524. doi: 10.1007/s00421-010-1500-0.

6. Ben-Zaken S1, Meckel Y, Nemet D, Eliakim A. Can IGF-I polymorphism affect power and endurance athletic performance? Growth Horm IGF Res. 2013;23(5):175-8. doi: 10.1016/j.ghir.2013.06.005.

7. Chaabène H, Hachana Y, Franchini E, Mkaouer B, Chamari K. Physical and physiological profile of elite karate athletes. Sports Med. 2012;42(10):82943. doi: 10.2165/11633050000000000-00000.

8. Blazević S, Katić R, Popović D. Popović, The effect of motor abilities

\section{Conflict of interests}

None of the authors declare competing financial interests.

on karate performance. Coll Antropol. 2006;30(2):327-33.

9. Katić R, Blazević S, Zagorac N. Zagorac, The impact of basic motor abilities on the specific motoricity performance in elite karateka. Coll Antropol. 2010;34(4):1341-5.

10. Palles C, Johnson N, Coupland B, Taylor C, Carvajal J, Holly J, et al., Identification of genetic variants that influence circulating IGF1 levels: a targeted search strategy. Hum Mol Genet. 2008;17(10):1457-64. doi: 10.1093/hmg/ddn034.

11. Lynch NA, Metter EJ, Lindle RS, Fozard JL, Tobin JD, Roy TA, et al., Muscle quality. I. Age-associated differences between arm and leg muscle groups. J Appl Physiol (1985). 1999;86(1):188-94.

12. Rantanen T, Era P, Heikkinen E. Heikkinen, Physical activity and the changes in maximal isometric strength in men and women from the age of 75 to 80 years. J Am Geriatr Soc. 1997;45(12):1439-45.

13. Chagnon YC, Rice T, Pérusse L, Borecki IB, Ho-Kim MA, Lacaille M, Paré C, et al. Genomic scan for genes affecting body composition before and after training in Caucasians from HERITAGE. J Appl Physiol (1985). 2001;90(5):1777-87.

14. Sun G, Gagnon J, Chagnon YC, Pérusse L, Després JP, Leon AS, et al. Association and linkage between an insulin-like growth factor-1 gene polymorphism and fat free mass in the HERITAGE Family Study. Int J Obes Relat Metab Disord. 1999;23(9):92935.

15. Krych-Garsztka K, Mizgajska-Wiktor, H, Goździcka-Józefiak A. An analysis of the regulatory region of the IGF1 
gene in professional athletes in youth sports teams. Human Mov. 2011; 12(3): 216-22. doi.10.2478/v10038011-0021-y.

16. Miyamoto-Mikami E, Murakami $\mathrm{H}$, Tsuchie H, Takahashi H, Ohiwa N, Miyachi M, et al. Lack of association between genotype score and sprint/power performance in the Japanese population. J Sci Med Sport.
2017; 20(1):98-103. doi: 10.1016/j.jsams.2016.06.005.

17. Williams AG1, Folland JP. Similarity of polygenic profiles limits the potential for elite human physical performance. J Physiol. 2008 Jan 1;586(1):113-21. doi. 10.1113/jphysiol.2007.141887. 